\title{
Structured derivatives contracts, hedging exchange appreciation and financial instability: Brail, China and Korea
}

JAN KREGEL *

\author{
INTERNATIONAL IMBALANCES, EXCHANGE \\ RATE ADJUSTMENT AND DERIVATIVES
}

There has been a great deal of discussion recently over the use of exchange rates to ameliorate international imbalances. At the same time many developed countries have embarked a highly expansionary monetary policies, expanding the types and amounts of securities held on central bank balance sheets and attempting to use these purchased to alter the shape of the yield curve by buying medium and longer term securities. These two policies are inter-related since effective monetary expansion and zero short term interest rates accompanied by extremely low medium term interest encourage interest rate arbitrage and a reach for yield amongst institutional and retail investors which tends to increase exchange rate volatility and produce unidirectional cumulative movements of exchange rates in surplus countries which may cause substantial financial instability in the countries whose currencies are under pressure to appreciate.

While it is often argued that these relative movements in exchange rates will aid the international balances of payments adjustment process, whether this is correct remains to be seen. However, export firms in countries with appreciating exchange rates will seek means to subvert an adjustment process based on reducing their profitability. Derivatives contracts have been crucial in subverting the impact of exchange rates on the adjustment process and thus on the profitability of export firms in surplus countries. I have already written on the role of derivatives in aggravating the Asian financial crisis (in the Cambridge Journal of Economics special

* Levy Economics Institute of Bard College. E-mail: jankregel@yahoo.com. 
number on the Asian Crisis) and this contribution is an extension to that line of argument. These notes deals with Brazil's episode in which the expectation of a sustained appreciation of the currency has led to investment banks selling structured derivative product to business firms and corporations seeking to offset the adjustment process that eventually led to such massive losses when the currency reversed trend that there were either bankruptcies or legal or defacto default on the contracts. But this is not the only example, for others see Dodd. The lessons to be drawn are as much in terms of the kinds of derivatives regulations that would be required to prevent instability as the dangers of creating an adjustment process that leads to market expectations of a sustained trend in the exchange rate.

\section{THE DEMAND FOR STRUCTURED DERIVATIVES BY EXPORT FIRMS}

In general countries experiencing expectations of a sustained appreciation of the exchange rate are countries with external trade surpluses. The appreciation of the exchange rate is thus to reduce the ability of their domestic exporters to compete with foreign producers. At the same time, these countries tend to have high growth rates, and the central banks usually employ high interest rates to slow activity. This not only exacerbates the appreciation due to capital inflows, it raises borrowing costs for domestic export firms. Thus, these firms will be ready clients for structured derivatives contracts that provide a means of lower their borrowing costs and earning additional income to offset the squeeze on profit markets caused by attempting to remain competitive in the face of an appreciating currency. All of the contracts discussed in the three cases (and these are not the only countries in which such contracts were offered) offered a combination of lower borrowing costs and an offset to falling profit margins.

BRAZIL

In Brazil the appreciation of the Real that started in 2007 was driven by a strong external performance that produced a current account surplus as well as strong direct investment inflows, attracted by investments in bio fuels and energy, as well as from an alternative to the dollar. Periods in which the Central Bank raised interest rates to cool the expanding economy tended to generate divergence of forward prices from interest rate parity and made arbitrage activity in which spotforward swaps become a substitute for the carry trade through the sale of $\$$ spot against forward purchase of the $\$$ attractive. This exerted additional pressure for appreciation of the Real besides that of normal short-term interest rate arbitrage.

In the recent perion, in difference from 1999 in 2008 Brazilian export firms with dollar exposure also appear to have been not only hedgers of their future receipts, but also speculators. A study by the BCB suggests that the majority of the foreign exchange derivative contracts of such firms tend to be for speculative pur- 
poses. This may have been to attempt to generate earnings from foreign exchange trading to offset the loss of competitiveness due to the appreciation of the currency.

In what has been reported as the standard strategy a firm would discount its forward dollar earnings with a bank, and accompany the transaction with a forward sale of the expected dollar receipts against Real. To offset the Real borrowing costs of the hedged forward dollars the firm would write an out of the money over the counter call option on the dollar, expecting the Real to continue to appreciate and the option to expire, the premium income to cover the borrowing costs. The result would be interest free three month money.

Firms were also offered more complex structured derivative contracts. One example was a contract with a two year maturity for differences with an out of the money strike. The difference between the spot and the strike was settled monthly with $100 \%$ leverage (2X). Thus Real appreciation allowed the firm to benefits by twice the rate of appreciation, and it would receive a monthly cash kicker in the form of the margin payment on the increased value of the position. However, the reported contracts had a cap on the gain on the contract of $20 \%$ at which time it was automatically terminated (see Delfim Netto). On the other hand, if the Real depreciated the firm would lose double the difference and face an additional cash commitment in the form of margin payments. But on the depreciation side there was no cap and thus no floor to the losses. Thus when the absolute value of the $\mathrm{R} / \$$ rate exceeds the strike at month end, the firm pays the bank the difference times 2. Since the difference is steeled monthly, losses may accumulate until the maturity of the contract. As Delfim Netto notes there is limited upside and unlimited downside for the firm taking such a contract.

The accompanying charts show the evolution of the dollar real exchange rate over the period of appreciation as well as after the outbreak of the financial crisis. A separate chart shows the evolution of the rate over the period around the crisis to help assess the impact of the crisis on the derivatives contracts outlined above. In two months from August to October the exchange rate moves from around 1.60 to 2.30 and eventually to around 2.50 two months later. This is a move of between $40 \%$ and $50 \%$. For an out of the money option that had been written at a strike of 1.70 would have produced a loss of Real 3.5 million on a notional contract of R10 million. Or if written at $2 \mathrm{X}$ leverage 7 million. With the dollar roughly stable at these levels, after nine months the firm would have accumulated a debt of six time the notional value of the contract. It is thus perhaps not surprising that a number of large export firms accumulated losses that quickly placed them in insolvency. The estimates are that Aracruz lost \$2,130 million, Grupo Votorantim Diversificado - $\$ 1,040$ million and Sadia $-\$ 360$ million.

The existence of these contracts not only created solvency problems for businesses, they acted in a procylical manner in the foreign exchange market, increasing the demand for dollars, as well as in the domestic money market, creating a sharp increase in demand for dollar liquidity.

Sadia reported a loss on derivative instruments of $\mathrm{R} \$ 777.4$ milion in the third semester of 2008. Its short position in dollars was estimated at US\$ 8,4 billion. Of 
total financing costs derivatives accounted for $\mathrm{R} \$ 2$ billion in the fourth semester of 2008 and $\mathrm{R} \$ 2.6$ bilion for the year.

The losses reported by Aracruz reached US\$2,13 billion on liquidation of 97 percent of its open positions. It is proposing a 15 year rescheduling of its debt to its major bank creditors including Itaú BBA, Santander, Merrill Lynch, JP Morgan, Citi, Goldman Sachs, Deutsche Bank, Calyon, BNP Paribas, ING e Barclays.

Grupo Votorantim reported losses of R $\$ 2.2$ billion, Ajinomoto do Brasil, had $\mathrm{R} \$ 180$ million in losses on derivative and other foreign exchange operations, among which $\mathrm{R} \$ 110$ due to non-deliverable forwards and $\mathrm{R} \$ 70$ million due to currency mismatches. Embraer has also reported R $\$ 179,3$ of costs in the fourth quarter.

At the end of October the Jorge Sant'Anna of Cetip repored that more than 500 firms held open positions in foreign exchange derivatives. However this short dollar exposure has been reduced fro $\$ 40$ billion to $\$ 20$ billion between 30 de September and 24 October of 2008. The survery prepared by the Agência Estado in October 2008 referring to positions for the first semester of 2008 showed 37 of 50 non-financial firms listed on Ibovespa with open derivative positions.

As mentioned, banks were also involved for their own account in this activity: Santander (with sixty firms as clients), Unibanco (33 firms) and Itaú (96 firms).The exposure was concentrated in target forward and swap contracts.

The majority of the firms involved are not public listed companies to that their positions become public only when there is a legal proceding concerning the validity of the derivative positions. Two examples are the Arantes group and Tok $\&$ Stok whose exposure was revealed through a judicial process. The losses for the Arantes group are estimated at R $\$ 200$ million to $\mathrm{R} \$ 250$ million.

Among firms that have reported open positions to CVM for hedging purposes in the third quarter include Lojas Americanas, Klabin, São Martinho, Inpar e Alpargatas; Marfrig, Vigor, Abyara, Cesp, CSN e VCP were also required to restate their financial filings to take derivative losses into account.

A large majority of the contracts come to maturity in the third quarter of 2009, by which time the dollar has again started to depreciate.

The possibility that hundreds of companies would attempt legal recourse to renegotiate their exposure to their derivatives=based contracts with issuing banks prompted provisional measure MP443 which made provision for government controlled Banco do Brasil and Caixa Econômica to acquire capital of private financial institutions. The MP also created an investment bank under CEF to acquire capital not just in the financial, but other sectors that could extend to construction companies. It also authorized the Central Bank of Brazil to put in place currency swap lines with other international central banks to increase the potential to provide liquidity to the market. It has also been suggested that Itaú merged with Unibanco in order to protect the smaller bank from its impending losses on derivatives contracts written to corporate clients. Votorantim acquired Aracruz in order to meet the derivatives losses of the latter, and Banco do Brasil has acquired a 50\% stake in Bank Votorantim and also acquired a near three-quarters share of Nossa Caixa. 
Overall, estimates are that the eight largest Brazilian banks will take losses on excess of $\$ 5$ billion as a result of their own positions or counterparty failures.

Thus, although the banks themselves apparently did not engage in the same kinds of originate and distribute activities as US banks, or investment in these assets to gain higher yields, the indirect impact through the exchange rate appreciation and rising asset prices produced conditions which were typical of prior crises, creating interest rate differentials that made short dollar positions attractive, and these were primarily pursued through derivative positions for their own book or to provide accommodation to their corporate clients. These activities were not sufficient to threaten the stability of the financial system, although a number of preventive merger actions were undertaken to ensure this result.

Thus, even though the Brazilian banking system is extremely stable, the operations of derivatives markets and in particular off shore derivatives markets have created instability, in both the financing of firms, but also in the financial institutions themselves and in the exchange rate.

All of these factors will tend to reinforce the appreciation of the currency and make it more difficult to ensure currency competitiveness in support of domestic industrialization and growth. The extremely large short dollar positions that accrued in September and October led to an extreme liquidity crisis in Brazilian money markets and required substantially released of liquidity by the Central Bank as well as accepting a $\$ 30$ billion swap line, in an attempt to calm markets without running down reserves.

\section{REFERENCES}

DELFIM NETTO, Antonio (2008) “Hedge tóxico," Valor, 14/10/2008.

FARHI, Maryse and Roberto Alexandre Zanchetta BORGHI (2009) "Operações com derivativos financeiros das corporações de economias emergentes no ciclo recente”, Estudos Avançados, 23 (66): 169-188.

OLIVEIRA, Fernando N. de and Walter NOVAES (2007) "Demand for foreign exchange derivatives in Brazil, hedge or speculation?”, Central Bank of Brazil Working Paper \# 152, December 2007.

PRATES, Daniela Magalhães and Maryse FARHI, (2009) “A crise financeira internacional, o grau de investimento e a taxa de câmbio do real”, Texto para Discussão IE/Unicamp 164, june 2009. 